\title{
The Unique Nutriceutical Components of the Ethnic Medicinal Plant-Codariocalyx Motorius
}

\author{
Guan Rong Li*, Rui Hua Ren, Jing Huang, Da Jin Lv and Wei Liu \\ College of Agronomy and Biotechnology, Sowthwest University, China
}

*Corresponding author: Guan Rong Li, Professor, College of Agronomy and Biotechnology, Southwest University, Chongqing 400716, China

\begin{abstract}
ARTICLE INFO
Received: 㗀 January 08, 2020

Published: 慧 January 21, 2020

Citation: Guan Rong Li, Rui Hua Ren, Jing Huang, Da Jin Lv, Wei Liu. The Unique Nutriceutical Components of the Ethnic Medicinal Plant-Codariocalyx Motorius. Biomed J Sci \& Tech Res 24(4)-2020. BJSTR. MS.ID.004096.
\end{abstract}

Abbreviations: DW: Dry Weight; FW: Fresh Weight; C.Motorius: Codariocalyx motorius; DMT N: N-Dimethyltryptamine; 5-MeO-DMT: 5-Methoxy-N, N-Dimethyltryptamine; DNS: 3, 5-Dinitro Salicylic Acid; SD: Standard Deviations; FA: Fatty Acid

\begin{abstract}
In this study, the nutriceutical components in the traditional medicinal plant of C. motorius were studied for the first time. Results showed that the soluble, reducing and total sugar contents in percentage by fresh weight were 13.1, 8.0 and 19.8 in roots, 7.2, 6.8 and 16.4 in stems, 8.5, 5.1 and 15.6 in leaves, and 7.9, 8.2 and 23.6 in seeds, respectively; crude fiber contents in percentage were 3.8, 5.7, 0.4 and 4.6 respectively; crude protein contents in percentage were $11.0,8.8,17.3$ and 22.4 , and soluble protein contents in percentage were 5.7, 4.9, 8.1 and 8.7 respectively; total amino acid contents in the hydrolytes of roots, stems, leaves and seeds were 4.52, 3.35, 18.2 and 18.86 $\mathrm{g} / 100 \mathrm{~g}$ dry weight and essential amino acid contents were 1.72, 1.41, 7.54 and 7.22 g/100 g DW respectively. Crude fat contents in percentage by FW were 9.2, 25.1, 12.5 and 8.5; and unsaturated fatty acid contents in percentage accounting for the total were $85.6,85.7,87.3$ and 82.2 respectively in roots, stems, leaves and seeds; especially high proportions of linoleic acid existed in different plant parts. The leaves uniquely contain an eicosenoic acid (5.6\%). Ca contents were 361.5, 563.4, 552.2 and $91.3 \mathrm{mg}, \mathrm{K}$ contents were $356.3,353.8,136.9$ and $123.8 \mathrm{mg}$, and $\mathrm{Mg}$ contents were 55.9, 54.1, 48.4 and $21.5 \mathrm{mg}$ respectively, by $100 \mathrm{~g}$ dry weight. The unique nutriceutical components in $C$. motorius suggests its great potential for further development as a novel oil and cosmetics resources plant besides the medicinal applications.
\end{abstract}

Keywords: Medicinal Plant; Codariocalyx Motorius; Nutriceutical Analysis

\section{Introduction}

Codariocalyx motorius (alias Desmodium motorium or D. gyrans or Hedysarum gyrans), also known as telegraph plant, dancing plant, or semaphore plant D Amato et al. [1,2] is a rare and endangered perennial leguminous woody plant belonging to the family Fabaceae Nair and Henry [3]. It is widely distributed throughout Banadesh, Bhutan, Cambodia, China, India, Indonesia, Laos, Malaysia, Nepal, Pakistan, Sri Lanka, Thailand and Vietnam Kalirajan et al. [4] The special ultradian rhythmic movements of the lateral leaflets interested many researchers and have been intensively studied. Each of the large leaves of the $C$. motorius has two small leaflets at its base. They move constantly along an elliptical path for up to a few minutes. The movements were sensitive to changes in a variety of external environmental factors such as light Sharma et al.
[5] temperature Ileperuma [6], high pitch sound waves Ellingsurd [7], etc. Moreover, the mechanism and biological significance of this movement have been studied in detail about the effects of chemicals, DC currents Johnsson et al. [8] and static magnetic fields Sharma et al. [9]

The ultradian rhythmic movement accompanied by rhythmic changes of the extra- and intracellular electrical potentials in the pulvinus; membrane depolarization in pulvinar motor cells drives and controls potassium efflux and hyperpolarization potassium influx via potassium channels; and the downward movement is preceded and accompanied by a strong depolarization and upward movement by hyperpolarization Antkowiak et al. [10] It was hypothesized that the movement is to obtain optimum sunlight 
for the larger leaves by sampling the intensity of sunlight and directing the large leaves to the area of most intensity, a possibly strategy to maximize light by tracking the sun Sharma et al. $[5,11]$ hypothesized that the rapid movements are intended to deter potential predators. C. motorius root has a long history of medicinal value. The roots leaves and flowers of $C$. motorius have been used in Chinese and Southeast Asian medicine for centuries to treat a medley of inflammatory ailments Kalirajan et al. [4] C. motorius has traditionally been used in Chinese medicine to treat various ailments such as rheumatism, wounds, cough, malaria, pyrexia, dysentery, hepatitis, hemoptysis, etc. and also used as a constituent in herbal tea Sharma et al. [5].

According to the Compendium of Materia Medica, the whole plant could be used as medicine, effective for relieving rigidity of muscles, promoting blood circulation, reducing phlegm and resolving masses Liu and Hao [12]. The leaf ointment can treat bone fractures and the stem- and branch- infused liquor can strengthen the physique and treat recurring illnesses such as rheumatic pain, double ribs ache, rheumatism and sciatica Wang [13]. The leaf juice can smooth and brighten the skin and maintain beauty and keep young Yang and Guo [14]. The plant can also be used to treat summer colds, toxic swellings, snakebites etc. Liu [15]. It has been widely used as an antidote, cardiac-tonic, wound healing ointment in Indian systems of medicine and also has antidysenteric property and used as a remedy for asthma and cough Ghosal et al. [16] There are also reports that the roots, stems and leaves of $C$. motorius contained small amounts of pharmacologically active substances such as tryptamine alkaloids, especially N, N-Dimethyltryptamine (DMT) and 5-methoxy-N, N-dimethyltryptamine (5-MeO-DMT) Chidambaram et al. $[17,18]$. The study of the ethanol root extract of $C$. motorius on blood glucose, insulin and carbohydrate metabolic enzymes in induced diabetic rats clearly demonstrated its antidiabetic effect by normalizing the key enzymes of carbohydrate metabolism and restoring the functions of pancreas Chidambaram et al. [19] The root extract possessed antioxidant potential as assessed by in vitro methods Chidambaram et al. [17]; its antimicrobial, phytochemical and wound healing properties have been screened and reported Kalirajan et al. [4] The toxic effects of the ethanol extract of $C$. motorius leaves in rats were observed from $2 \mathrm{~g} / \mathrm{kg}$ body weight orally by gavage Gopalakrishnan et al. [20].

So far, the nutriceutical products on Chinese market based on C. motorius have been mainly the Extracts of Dancing Grass from Runxue Bio Co Ltd located in Xian, China. They are powders made from the whole plant (http://china.makepolo.com/productdetail/100272088432.html); it is also one of the ingredients of the Spring Palace Yulu Wine made by Guangzhou Longhui Wine Industry Co. Ltd (http://exam4493.china.herostart.com/). However, to the best of our knowledge, the nutriceutical components of this plant has not yet reported. In this research, the major components in the roots, stems, leaves and seeds of $C$. motorius, including proteins and amino acids, fat and fatty acids, various carbohydrates and minerals, were systematically analyzed in a hope to understand its nutriceutical value and lay a basis for further research and development of $C$. motorius related products.

\section{Materials and Methods}

Seeds of $\boldsymbol{C}$. Motorius: seeds were purchased from Beijing Nan Wu Kemao Limited Co and sowed in September 2015 and cultivated in open field of Beibei District $\left(106^{\circ} 25^{\prime} 22^{\prime \prime} \mathrm{E}-29^{\circ} 49^{\prime} 35^{\prime \prime} \mathrm{N}\right.$, latitude $247 \mathrm{~m}$ ASL), Chongqing, China. One-year old plants in October 2016 were sampled.

Determination of Moisture Contents: one-gram samples of the roots, stems, leaves and seeds from the one-year old $C$. motorius plants were dried in an oven at $105 \pm 2^{\circ} \mathrm{C}$ with ambient pressure constant weight method to determine the moisture contents of the samples Nan et al. [21] Triplicates were performed.

Determination of Crude Protein Contents: crude protein contents were determined by micro Kjeldahl method Zhang, et al. [22] with Foss Kjeltec 2300 Nitrogen Analyzer. Contents of crude proteins $(\%)=$ Nitrogen contents $(\%) \times 6.25$. Triplicates were performed.

Determination of Soluble Protein Contents: Bradford Protein Assay Li et al. [23] was applied to determine soluble protein contents. Triplicates were performed.

Analysis of Amino Acids: contents of amino acids in the hydrolytes of the roots, stems, leaves and seeds were determined according to Nan et al. [21] with Hitachi L-8800 Amino Acid Analyzer; and tryptophan was determined by photometry with p-dimethylaminobenzaldehyde Liu et al. [24].

Determination of Crude Fat and Relative Fatty Acid Contents: crude fat contents were determined by Soxhlet extraction method Ning [25]; and relative contents were determined by gas chromatography with Shimadzu GC 2100 Nan et al. [26] Triplicates were performed.

Determination of Carbohydrate and Crude Fiber Contents: the soluble sugar contents were determined by anthrone method $\mathrm{Li}$ et al. [23]; the reducing and total sugar contents were determined by 3, 5-dinitro salicylic acid (DNS) He et al. [27]; and crude fiber contents were determined by gravimetric method He et al. [27]. Triplicates were performed.

Determination of Mineral Contents: minerals, Fe, Zn, Mn, $\mathrm{Cu}, \mathrm{Mg}$, Ca and $\mathrm{K}$, were determined by TAS-990 Atomic Absorption Spectrophotometer Nan et al. [26] Triplicates were performed.

Data Processing: all data except for amino acids are presented as means \pm standard deviations (SD) and were statistically analyzed by using the software package SPSS 13.0 (Chicago, IC, USA). 


\section{Results and Analyses}

\section{Moisture and Carbohydrate Contents in the Different Plant Parts of $C$. Motorius}

The moisture contents were $55.0 \%, 40.1 \%, 45.6 \%, 31.4 \%$; crude fiber contents, $3.8 \%, 5.7 \%, 0.4 \%, 4.6 \%$; soluble sugar contents,
5.9\%, 4.3\%, 4.6\%, 5.4\%; reducing sugar contents 3.6\%, 4.1\%, $2.8 \%, 5.6 \%$ and total sugar contents $13.2 \%, 11.0 \%, 8.2 \%, 14.8 \%$, respectively in the roots, stems, leaves and seeds of $C$. motorius (Table 1). The contents of the carbohydrates on fresh weight basis (FW) in all plant parts were relatively low. All the contents are significantly different among the different plant parts (Table 1).

Table 1: Moisture and carbohydrate contents in different plant parts of C. motorius (\% FW).

\begin{tabular}{|c|c|c|c|c|c|}
\hline & Moisture content & Crude fiber & Soluble Sugar & Reducing Sugar & Total sugar \\
\hline Roots & $49.2 \pm 1.3 \mathrm{a}$ & $8.0 \pm 0.12 \mathrm{~b}$ & $13.1 \pm 0.24 \mathrm{a}$ & $8.0 \pm 0.07 \mathrm{~b}$ & $19.8 \pm 0.05 \mathrm{~b}$ \\
\hline Stems & $40.1 \pm 1.0 \mathrm{c}$ & $8.6 \pm 0.22 \mathrm{a}$ & $7.2 \pm 0.25 \mathrm{~d}$ & $6.8 \pm 0.05 \mathrm{c}$ & $16.4 \pm 0.03 \mathrm{c}$ \\
\hline Leaves & $45.6 \pm 1.2 \mathrm{~b}$ & $3.5 \pm 0.02 \mathrm{~d}$ & $8.5 \pm 0.21 \mathrm{~b}$ & $5.1 \pm 0.04 \mathrm{~d}$ & $15.6 \pm 0.04 \mathrm{~d}$ \\
\hline Seeds & $33.4 \pm 0.1 \mathrm{~d}$ & $6.7 \pm 0.20 \mathrm{c}$ & $7.9 \pm 0.20 \mathrm{c}$ & $8.2 \pm 0.09 \mathrm{a}$ & $23.6 \pm 0.06 \mathrm{a}$ \\
\hline
\end{tabular}

Note: The values are represented as mean \pm SD $(n=3)$ and except moistures all are based on fresh weight. Data in the same column with different lowercase letters are significantly different at $\mathrm{P} \leq 0.05$.

\section{Protein and Amino Acids Contents and Analysis}

The contents of crude and soluble proteins in the four different plant parts of $C$. motorius are significantly different, with seeds > leaves $>$ roots $>$ stems (Table 2). The hydrolytes of the roots and stems contained 18 amino acids and the hydrolytes of the leaves and seeds contained 19 amino acids (one extra being cysteine in the form of cystine). The total contents of amino acids (tryptophan included) in the hydrolytes of the roots, stems, leaves and seeds were respectively 4.52, 3.35, 18.2 and 18.86 g/100 g DW, among which essential amino acids accounted for 1.72, 1.41, 7.54 and 7.22 $\mathrm{g} / 100 \mathrm{~g}$ DW respectively. In summary, the contents of total, essential amino acids in the leaves and seeds all were comparable and higher than in the roots and stems (Table 3).

Table 2: Crude and soluble protein contents in the different plant parts of C. motorius (\% FW).

\begin{tabular}{|c|c|c|c|c|}
\hline & Roots & Stems & Leaves & Seeds \\
\hline $\begin{array}{c}\text { Crude } \\
\text { Protein }\end{array}$ & $11.1 \pm 0.1 \mathrm{c}$ & $8.8 \pm 0.0 \mathrm{~d}$ & $17.3 \pm 0.1 \mathrm{~b}$ & $22.4 \pm 0.22 \mathrm{a}$ \\
\hline $\begin{array}{c}\text { Soluble } \\
\text { Protein }\end{array}$ & $5.7 \pm 0.0 \mathrm{c}$ & $4.9 \pm 0.0 \mathrm{~d}$ & $8.1 \pm 0.09 \mathrm{~b}$ & $8.7 \pm 0.14 \mathrm{a}$ \\
\hline
\end{tabular}

Notes: Data are represented as mean $\pm S D(n=3)$ based on fresh weight and different lowercase letters in the same row indicate significance at $\mathrm{P} \leq 0.05$.

\section{Crude Fat and Relative Fatty Acid Contents and Analysis}

The stems of $C$. motorius showed the highest crude fat contents (up to $25.1 \%$ ), followed by the leaves $(12.5 \%)$, roots $(9.2 \%)$ and seeds (8.5\%). The relative contents of unsaturated fatty acids were very high, $85.57 \%, 85.66 \%, 87.25 \%, 82.20 \%$ respectively in the
Table 3: Amino acid contents in the hydrolytes of different plant parts of C. motorius (g/100 g DW).

\begin{tabular}{|c|c|c|c|c|}
\hline & Roots & Stems & Leaves & Seeds \\
\hline Asp & 0.526 & 0.358 & 1.772 & 2.195 \\
\hline Thr & 0.194 & 0.162 & 0.85 & 0.808 \\
\hline Ser & 0.222 & 0.179 & 0.82 & 0.816 \\
\hline Glu & 0.433 & 0.348 & 1.892 & 3.131 \\
\hline Gly & 0.231 & 0.202 & 1.2 & 1.052 \\
\hline Ala & 0.271 & 0.236 & 1.356 & 0.982 \\
\hline Cystine & nd & nd & 0.078 & 0.167 \\
\hline Val & 0.334 & 0.276 & 1.150 & 1.128 \\
\hline Met & 0.046 & 0.040 & 0.140 & 0.237 \\
\hline Ile & 0.229 & 0.193 & 1.063 & 0.989 \\
\hline Leu & 0.395 & 0.327 & 2.192 & 1.776 \\
\hline Tyr & 0.131 & 0.077 & 0.734 & 0.597 \\
\hline Phe & 0.226 & 0.193 & 1.038 & 1.078 \\
\hline Lys & 0.321 & 0.217 & 1.106 & 1.197 \\
\hline Free $\mathrm{NH}_{3}$ & 0.115 & 0.095 & 0.260 & 3.821 \\
\hline Val & 0.199 & 0.117 & 0.476 & 0.078 \\
\hline Arg & 0.402 & 0.197 & 1.302 & 1.914 \\
\hline Pro & 0.353 & 0.230 & 1.032 & 0.705 \\
\hline Trp & 0.002 & 0.001 & 0.003 & 0.007 \\
\hline Total amino acids & 4.52 & 3.35 & 18.20 & 18.86 \\
\hline Total essential amino acids & 1.72 & 1.41 & 7.54 & 7.22 \\
\hline
\end{tabular}

Note: nd: not detected.

roots, stems, leaves and seeds. Among them, the total contents of essential fatty acids (linoleate and linoleate) were rather high in all the plant parts, accounting for $34.3 \%, 40.4 \%, 41.5 \%$ and $53.7 \%$ respectively in the roots, stems, leaves and seeds. It is worthy to note that a unique fatty acid, eicosenoate, was detected only in the leaves, accounting for $5.6 \%$ (Table 4). 
Table 4: Contents of crude fat (FW \%) and fatty acid (FA) composition in different plant parts of C. motorius (Relative \%).

\begin{tabular}{|c|c|c|c|c|}
\hline & Roots & Stems & Leaves & Seeds \\
\hline Crude fat & $9.2 \pm 0.35 \mathrm{C}$ & $25.1 \pm 1.3 \mathrm{~A}$ & $12.5 \pm 0.62 \mathrm{~B}$ & $8.5 \pm 0.54 \mathrm{C}$ \\
\hline C $16: 0$ Palmitate & $9.8 \pm 0.25 \mathrm{C}$ & $10.9 \pm 0.32 \mathrm{~B}$ & $9.0 \pm 0.22 \mathrm{D}$ & $11.6 \pm 0.26 \mathrm{~A}$ \\
\hline C $18: 0$ Stearate & $3.6 \pm 0.02 \mathrm{~B}$ & $3.5 \pm 0.02 \mathrm{C}$ & $2.8 \pm 0.01 \mathrm{D}$ & $5.3 \pm 0.04 \mathrm{~A}$ \\
\hline C $18: 1$ Oleate & $51.3 \pm 0.43 \mathrm{~A}$ & $45.2 \pm 0.42 \mathrm{~B}$ & $40.1 \pm 0.37 \mathrm{C}$ & $28.5 \pm 0.12 \mathrm{D}$ \\
\hline C $18: 2$ Linoleate & $22.9 \pm 0.11 \mathrm{C}$ & $27.9 \pm 0.22 \mathrm{~B}$ & $17.2 \pm 0.09 \mathrm{D}$ & $44.5 \pm 0.39 \mathrm{~A}$ \\
\hline C $18: 3$ Linolenate & $11.4 \pm 0.09 \mathrm{C}$ & $12.5 \pm 0.11 \mathrm{~B}$ & $24.3 \pm 0.11 \mathrm{~A}$ & $9.2 \pm 0.15 \mathrm{D}$ \\
\hline C $20: 1$ Eicosenoate & $0.00 \mathrm{~B}$ & $0.00 \mathrm{~B}$ & $5.6 \pm 0.03 \mathrm{~A}$ & $0.00 \mathrm{~B}$ \\
\hline Unsaturated FA & $85.6 \pm 0.31 \mathrm{~B}$ & $85.7 \pm 0.26 \mathrm{~B}$ & $87.3 \pm 0.21 \mathrm{~A}$ & $82.2 \pm 0.33 \mathrm{C}$ \\
\hline Essential FA & $34.3 \pm 0.10 \mathrm{D}$ & $40.5 \pm 0.16 \mathrm{C}$ & $41.5 \pm 0.10 \mathrm{~B}$ & $53.7 \pm 0.23 \mathrm{~A}$ \\
\hline
\end{tabular}

Notes: values are represented as mean $\pm S D(n=3)$. Data in the same row with different uppercase letters are significantly different at $\mathrm{P} \leq 0.01$.

Comparison of the Major Nutritional Components of $C$. Motorius with Common Crop Seeds

Compared with other major crops, the carbohydrates in $C$. motorius were lower, crude proteins were higher than rice and

millet, comparable to wheat flour, but lower than legumes (soya bean, mung bean and garden pea). Crude fat contents of $C$. motorius were relatively high, especially in the stems, much higher than in soya bean (Table 5).

Table 5: Comparison of the major nutrients of C. motorius with some common crop seeds (/100 g).

\begin{tabular}{|c|c|c|c|}
\hline & Crude Protein $\mathbf{( g )}$ & Crude Fat (g) & Total Sugar(g) \\
\hline Rice & 7.5 & 0.5 & 79.0 \\
\hline Millet & 9.7 & 1.7 & 77.0 \\
\hline Wheat flour & 12.0 & 0.8 & 70.0 \\
\hline Soya bean & 39.2 & 17.4 & 25.0 \\
\hline Mung bean & 22.1 & 0.8 & 59.0 \\
\hline Garden pea & 24.0 & 1.0 & 58.0 \\
\hline C. motorius roots & 11.1 & 9.2 & 19.8 \\
\hline C. motorius stems & 8.8 & 25.1 & 16.4 \\
\hline C. motorius leaves & 17.3 & 12.5 & 15.6 \\
\hline C. motorius seeds & 22.4 & 8.5 & 23.6 \\
\hline
\end{tabular}

Note: Data other than C. motorius are from, http:/ / www.people.com.cn/GB/14739/14745/21522/2907407.html.

\section{Mineral Contents and Analysis}

The calcium contents in the roots, stems and leaves of $C$. motorius were all shown to be the highest among the other minerals, accounting for 361.48, 563.28, 552.15 mg/100g DW respectively, followed by potassium, respectively $356.3,353.8,136.9 \mathrm{mg} / 100 \mathrm{~g}$ DW, and then magnesium, respectively 55.9, 54.1, $48.4 \mathrm{mg} / 100 \mathrm{~g}$ DW. In the seeds, potassium content is the highest $(123.8 \mathrm{mg} / 100 \mathrm{~g}$ DW), followed by calcium ( $91.3 \mathrm{mg} / 100 \mathrm{~g}$ DW) and then magnesium (21.6 mg/100 g DW) (Table 6).

Table 6: Mineral Contents of in the different plant parts of C. motorius (mg/100 g DW).

\begin{tabular}{|c|c|c|c|c|}
\hline & Roots & Stems & Leaves & Seeds \\
\hline $\mathrm{Fe}$ & $27.8 \pm 3.80 \mathrm{~A}$ & $6.6 \pm 0.90 \mathrm{~B}$ & $7.9 \pm 1.10 \mathrm{~B}$ & $1.4 \pm 0.19 \mathrm{C}$ \\
\hline $\mathrm{Zn}$ & $1.9 \pm 0.02 \mathrm{~A}$ & $1.3 \pm 0.01 \mathrm{C}$ & $1.8 \pm 0.02 \mathrm{~B}$ & $1.1 \pm 0.01 \mathrm{D}$ \\
\hline $\mathrm{Mn}$ & $4.0 \pm 0.44 \mathrm{C}$ & $11.7 \pm 1.29 \mathrm{~B}$ & $15.2 \pm 1.69 \mathrm{~A}$ & $0.8 \pm 0.09 \mathrm{D}$ \\
\hline $\mathrm{Cu}$ & $1.5 \pm 0.09 \mathrm{~B}$ & $2.3 \pm 0.15 \mathrm{~A}$ & $1.5 \pm 0.10 \mathrm{~B}$ & $0.8 \pm 0.05 \mathrm{C}$ \\
\hline $\mathrm{Mg}$ & $55.9 \pm 1.62 \mathrm{~A}$ & $54.1 \pm 1.57 \mathrm{~A}$ & $48.4 \pm 1.40 \mathrm{~B}$ & $21.5 \pm 0.62 \mathrm{C}$ \\
\hline $\mathrm{Ca}$ & $361.4 \pm 10.12 \mathrm{~B}$ & $563.4 \pm 15.82 \mathrm{~A}$ & $552.2 \pm 15.45 \mathrm{~A}$ & $91.3 \pm 2.56 \mathrm{C}$ \\
\hline $\mathrm{K}$ & $356.3 \pm 14.25 \mathrm{~A}$ & $353.8 \pm 14.15 \mathrm{~A}$ & $136.9 \pm 5.48 \mathrm{~B}$ & $123.8 \pm 4.93 \mathrm{~B}$ \\
\hline
\end{tabular}

Notes: Data are represented as mean $\pm S D(n=3)$ and different uppercase letters in the same row indicate significance at $P \leq 0.01$. 


\section{Conclusion and Discussion}

To the best of our knowledge, this report is the first addressing the major nutriceutical components in the medicinal plant $C$. motorius. It was found that the crude protein content in C. motorius is higher than rice and millet, comparable to wheat flour, but lower than several other legumes; the contents of total, essential and semi-essential amino acids in hydrolytes of the leaves and seeds are higher than in the roots and stems. It is worthy to note that there was no detectable amount of cysteine in the hydrolytes of both the roots and stems.

The soluble, reducing and total sugar contents in different plant parts of $C$. motorius were all relatively low; crude fiber contents were moderate. Crude fat contents are especially high in the stems, up to $27.1 \%$, far greater than soya bean. Thus, C. motorius is suitable to extend in cultivation and to be developed into a novel source of oil plant. The relatively high crude fat contents in the stems may also account for the easy breaking of its stems and branches by natural forces such as wind in field conditions as observed; the relative contents of the unsaturated fatty acids in various plant parts were high, $82 \%$ above; and among which essential fatty acids, linoleate and linolenate, are very high.

They are components of the cell membranes and precursors for the biosynthesis of signaling molecules eicodanoids such as prostaglandins, cycloprostaglandins, thromboxane, leukotriene, etc. Zielińska et al. [28,29] Encyclopedia of Life Support Systems). They are also involved in the transport and oxidation of cholesterols, lack of which will lead to vascular brittleness, the slowdown of the immune system process, and the interference of blood clotting and the increase of the possibility of atherosclerosis occurrence Zielińska et al. [28] As vegetable oils are important in cosmetic industry because of their beneficial effects on the skin Nan et al. [26], it is suggested that oils from C. motorius can be developed for use in cosmetic industry. It is very interesting to note that the leaves of $C$. motorius uniquely contained an unsaturated $\omega-9$ fatty acid, eicosenoic acid (5.6\%). It is the main acid component in the jojoba oil, the so-called "liquid gold" [30], with very good nourishing and moisturizing effects on the skin. The reason why the leaves contains this unique fatty acid and its possible physiological role are worthy of further studying. Whether this high proportions of unsaturated fatty acids and unique eicosenoic acid in the leaves has something to do with the dancing of this plant is of interest for further studying. Calcium contents were the highest in the roots, stems and leaves among the other minerals, followed by potassium, and then magnesium. The types and contents of minerals in plantbased medicines are the major determinants of the four natures of the Chinese medicines: "hot, warm, cool and cold" [31,32]. The whole plant of $C$. motorius can be used as medicine to keep fit, treat bone fracture. These health-protecting and therapeutic effects are most likely due to the presence of these unique contents of minerals in C. motorius. This study for the first time discovered the unique pattern of nutriceutical composition of the $C$. motorius. It provides an excellent basis for further studying of the medicinal properties and for the development of health-protecting products of $C$. motorius.

\section{Acknowledgement}

This work was supported by the Crop Germplasm Resources Utilization and Innovation Base program of the 111 Project of China (104510-205001).

\section{References}

1. D Amato, Peter (2016) The Telegraph Plant by Peter D Amato. California Carnivores.

2. Lowry, Connor (2013) Weird and Unusual Plant: The Dancing Plant (Codariocalyx Motorius). Fun Flower Facts.

3. Nair NC, Henry AN (1983) Flora of Tamil Nadu, India. Series I: Analysis, Volume I. Botanical Survey of India: Coimbatore.

4. Kalirajan A, Savarimuthu J, Michael, AJA Ranjit Singh (2012) A preliminary screening of the medicinal plant Desmodium gyrans (Linn F) DC for its antimicrobial, phytochemical and wound healing properties. International Journal for Pharmaceutical Sciences and Research, India.

5. Sharma VK, Bardal TK, Johnsson A (2003) Light-dependent changes in the leaflet movement rhythm of the plant Desmodium gyrans. Zeitschrift für Naturforschung 58: 81-86.

6. Ileperuma CVK (2015) The 'dancing' plant: Codariocal motorius (Houtt.) Ohashi. Sciscitator 2: 13-14.

7. Ellingsurd S (1993) Perturbations of plant leaflet rhythms caused by electromagnetic radio-frequency radiation Bioelectromagnetics 14(3): 257-271.

8. Johnsson A, Bostrom AC, Pederson M (1993) Perturbation of the Desmodium leaflet oscillation by electric current pulses. Journal of Interdisciplinary Cycle Research 24(1): 17-32.

9. Sharma VK, Engelmann W, Johnsson A (2000) Effects of static magnetic field on the ultradian leaf movement rhythm in Desmodium gyrans. Zeitschrift für Naturforschung 55(7): 638-642.

10. Antkowiak B, Mayer WE, Engelmann W (1991) Oscillations of the membrane potential of pulvinar motor cells in-situ in relation to leaflet movements of Desmodium gyrans. Journal of Experimental Botany 42: (24): 901-910.

11. Simcha Lev Yadun (2013) The enigmatic fast leaflet rotation in Desmodium motorium: Butterfly mimicry for defense? Plant Signaling and Behavior 8(6): e24473.

12. Liu J, Hao JL (2008) On the dancing grass, Agricultural Engineering Technology (Greenhouse Horticulture) (2): 62.

13. Wang XJ (2001) Excellent economic efficiency in cultivation the dancing grass, Jilin Vegetables 1: 21.

14. Yang SS, Guo JS (2002) The seed germination and cultivation of the special ornamental plant, Codariocalyx motorius. Shaanxi Forest Science and Technology 4: 85-91.

15. Liu Z (2007) The beautiful dancing grass. Zhejiang Forestry (3): 13.

16. Ghosal S, Mazumder UK, Mehta R (1972) Indole bases of Desmodium gyrans. Phytochemistry 11: 1863-1864.

17. Chidambaram U, Pachamuthu V, Natarajan S, Elango B, Suriyanarayanan et al. (2013) In vitro evaluation of free radical scavenging activity of Codariocalyx motorius root extract. Asian Pacific Journal of Tropical Medicine 6(3): 188-194.

18. Ma XQ Zheng CJ, Hu CL, Rahman K, Qin LP, et al. (2011) The genus Desmodium (Fabaceae)-traditional uses in Chinese medicine, phytochemistry and pharmacology. Journal of Ethnophamarcology 138(2): 314-332. 
19. Chidambaram U, Suganya N, Vanitha P, Bhakkiyalakshmi E, Suriyanarayanan S, et al. (2014) Antihyperycemic effect of Codariocalyx motorius modulated carbohydrate metabolic enzyme activities in streptozotocin-induced diabetic rats. Journal of Functional Foods 11: 517-527.

20. Gopalakrishnan S, Rajameena R (2012) Evaluation of ethanolic extract of desmodium gyrans DC leaves on wound healing activity in rats. Pharmaceutica Analytica Acta 3: 1-5.

21. Nan ZQ, Huang J, Yang HY, Li SH, Li GR (2012) Nutritional Analysis of Abelmoschus sagittifolius. Amino Acids and Biotic Resources 34(2): 6365.

22. Zhang ZL, Qu WJ, Li XF (2008) Experiment Manual of Plant Physiology, ( $4^{\text {th }}$ Edn.), Higher Education Press Beijing, China.

23. Li GR, Li TJ, Feng JC (2011) Biochemistry Lab Course, Agricultural University Press, Beijing, China.

24. Liu ZS, Li YC, Zhang XM (1998) Determination of tryptophan content in forages by colorimetry with p-dimethylaminobenzaldehyde. Feed Industry 19(6): 21-22.

25. Ning ZX (1998) Food Composition Analysis Manual. Light Industry Press, Beijing, China.

\section{ISSN: 2574-1241}

DOI: $10.26717 /$ BJSTR.2020.24.004096

Guan Rong Li. Biomed J Sci \& Tech Res

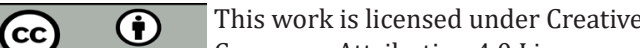

Submission Link: https://biomedres.us/submit-manuscript.php
26. Nan ZQ, Niu XD, Ai Y, Yang HY, Li GR, et al. (2012) Nutritional Analysis of Qianjiang Kidney bean. Journal of Southwest Normal University 37(2): 88-92.

27. He KY, Li GR (2013) Biochemstry Labwork Guide, Science Press, Beijing, China.

28. Zielińska A, Nowak I (2014) Fatty acids in vegetable oils and their importance in cosmetic industry. CHEMIK 68(2): 103-110.

29. Tvrzická E, Žák A, Vecka M, Staňková B Fatty Acids in Human Metabolism. Kapitola 6.54.3.5 in Physiology and Maintenance, from Encyclopedia of Life Support Systems (EOLSS), Developed under the Auspices of the UNESCO, Eolss Publishers, Oxford, UK.

30. Miwa Thomas (1971) Jojoba oil wax esters and derived fatty acids and alcohols: gas chromatographic analysis. Journal of the American Oil Chemists Society 48(6): 259-264.

31. Ergil MC, Ergil KV (2009) Pocket Atlas of Chinese Medicine. Georg Thieme. New York-Stuttgart: ISBN 978-3-13-141611-7.

32. Liu ZS, Li YC, Zhang XM (1998) Determination of tryptophan content in forages by colorimetry with p-dimethylaminobenzaldehyde. Feed Industry 19(6): 21-22.

$\begin{array}{ll}\text { BIOMEDICAL } & \text { Assets of Publishing with us } \\ \text { RESEARCHES } & \text { - Global archiving of articles } \\ \text { - Immediate, unrestricted online access }\end{array}$

